\title{
Mixed Cultural Representation of Stuart's Character in Minions As a Symbol of Strength and Protection
}

\author{
Zaini Ramdhan ${ }^{1}$ \\ ${ }^{1}$ Faculty of Creative Industries, \\ Visual Communication Design Departement \\ , Telkom University \\ Dayeuhkolot 40258 /Bandung, Indonesia \\ zainir@telkomuniversity.ac.id
}

\begin{abstract}
The myth of the one eye symbol is a symbol of the symbolism of symbols that are still unclear and hidden visual signs. Interpretations can be unclear and varied, Connecting with the sign of the Illuminati, the sun god with the eye symbol depicted single or one will have a psychological impact on the one who reads it. History records of artifacts made about the shape of the eye symbol and other forms. It is in ancient religious symbols of worship and leadership. The Sumerians demonstrated the sanctity of certain sculptures, the shape of the eyes enlarged by an abnormal size gave the impression, the message of sensation from the statue. Making performances of religious ceremonies, artists seek to bring sculptures to life in the way they do eye openings. The ancient Egyptian civilization was the originator of the disembodied eye as a symbol of the single eye. One of the well-known symbols of Egypt is the eye of the sun god in Pharaoh's mythology. The image is a mixture of the image of a human eye combined with an eagle's eye, with eyebrow markings, dark cheek markings of a bird. And also various forms of the relics of the modern era associated with the shape of the image of the one eye. In this case, Semiotics is a branch of science that studies a sign. Semiotics comes from the Greek word: semeion, which means sign. Sign as something that represents something; metaphor. The process of a sign as a representative occurs when the sign is reinterpreted concerning what it represents, in the form of visual forms, colors in works of art. It can be said that Semiosis is a process in which the sign becomes a function as a representative of the signified. The focus of researchers in the study of semiotics here is a visual sign of combining entities that are used as representations of the represented entities. This representation process is often called signification. This research is how the visual sign of the one eye on the animated minion character named Stuart can be a representation of the one eye symbol in the past and modern era that represents it both in shape and color.
\end{abstract}

Keywords: Symbol, Representation, Minion 


\section{Introduction}

In the world of entertainment produced by animated filmmakers from Hollywood, one of which was famous and became a box office in America and also in Indonesia, the storyline is good and the animated characters are funny and strange, one of which is the animated film Despicable Me which was released in 2017. In the story, there are minion characters played by Kevin, Stuart, and Bob. Even according to the literature from the Conspiracy Theories discourse and published in one of these articles, it has been aired on Warta Kota live.com with the title surprising facts, apparently, this is the origin of the Minions and they are real, they are Nazi children who are used as experimental projects whose lives are full of suffering. Under a Nazi concentration camp. His life was very miserable. They are described as minions who are very hungry because of suffering under heavy pressure. The most popular fruit food is bananas.
One of the minion characters that fit the minion nation's background is the character Stuart in the $3 \mathrm{D}$ animated film Despicable me where Stuart has expertise in music. Stuart is very good at strumming the ukulele guitar. Sometimes, his ukulele guitar must be damaged because of his own behavior. Stuart also often makes jokes that can make us laugh with his funny behavior. The character of Stuart itself is physically described as one-eyed with a striking color combination of yellow skin and blue clothes. Here it is interesting to analyze the existing myths about the one eye. Perceptions related to visuals are closely related to certain cultures about and understanding of the beholder. In particular, the perception that the eye is represented in an isolated structure has its own inherent psychological impact, indicating authority and for the viewer implying lively vigilance. One eye mythology exists in Egyptian culture. The Sumerians imparted sanctity to certain sculptures with eyes becoming abnormally large in 
size to create a sensation of obedient alertness according to their mythology. Hold a ritual ceremony where the artists and statues are brought to life by opening the eyes of the figures. This sign perception can be seen with semiotic language, especially how to understand these signs and symbols based on relational relationships. This research uses an interpretation analysis method with qualitative data. How the analysis is developed in a theoretical and interpretative approach, namely giving an impression, giving opinions and theoretical views on something; interpretation.

\section{Visual Theory and Research}

\section{Background}

\subsection{Stuart (Despicable Me)}

The background story of Stuart's character is fun, friendly, intelligent, and funny, he is skilled at playing video games like his friend Dave. Stuart can also be the most sincere and innocent of all the Minions. Stuart also seems to have a rebellious and rude attitude. Stuart is considered lazy among the Minions, preferring to relax and play the ukulele guitar rather than listen to the rules. Stuart is said to be always hungry among the other Minions, such as when he tried to eat Kevin and Bob when Stuart thought of them as bananas, and even tried to eat a yellow fire hydrant in New York, also thinking of them as banana food. That's the other side of the plot of the character Stuart in the animated film Despicable Me.

\subsection{Character Model Design}

According to Tony White's theory of physical character, Brian Tillman stated that the structure for designing character models for animation is as follows; The shape, proportion of a character can display the nature, personality of the inherent character. Tillman (2012:68) gives three basic forms attached to its nature there are three forms: 1. Square, 2. Round, 3. Triangle. 


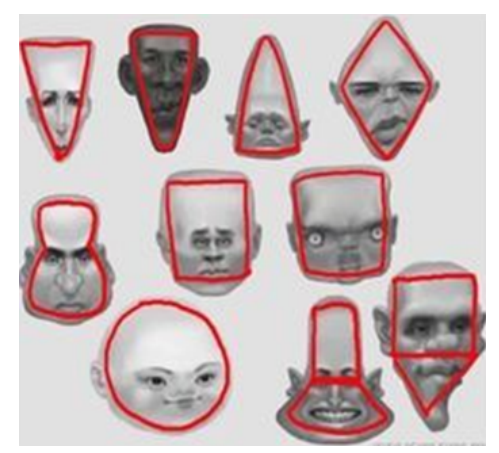

Pigures1: Head Shape Image source

The structure of the head shape, generally the human structure has a size of seven or eight head height, the more we draw a character with a size of more or less than eight or seven head height will produce a character that looks very exaggerated and like a cartoon (White, 2012:37).
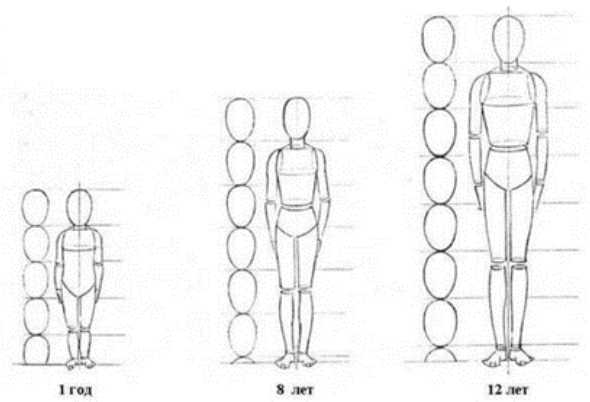

Pigures 2 : Structure Head Shape Image source

The visual creation of characters is displayed in color models (CMYK, RGB) which better explain the colors and textures used in the characters (White,
2012:39). Making this color model can be used as a reference at the animation production stage so that the visual characters displayed have consistent colors. Color also has a symbolic meaning and has a message to be displayed. In addition, the design of the animated model character has a variety of styles in its narrative. Here's the attached data on Stuart's character designs:

Table 1 : Stuart anatomy Character

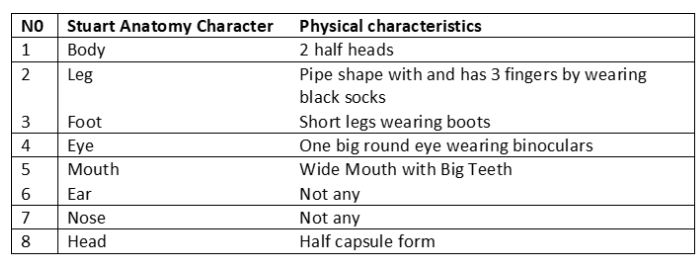

Table 2 : Stuart Personality Character

\begin{tabular}{|l|l|}
\hline N0 & Personality characteristics \\
\hline 1 & Playful \\
\hline 2 & Friendly \\
\hline 3 & Intelligent \\
\hline 4 & Funny \\
\hline 5 & Skillful \\
\hline 6 & Play Guitar Ukulele \\
\hline
\end{tabular}

\subsection{Visual Semiotics}

Images are included in the form of symbols, with visual messages in the form of visuals: line structure, color structure, composition. its existence is included in the category of non-verbal 
language communication. written verbal communication.

The development of graphic design into visual communication design uses a lot of medium of communication power from image/visual elements that serve as visual messages, with more effective communication power. Visual communication in the message element that visual communication contains the character of the message even becomes special by causing a certain impact from what it observes. Sign language or semiotics. Semiotics is a science that studies various signs. Signs can communicate communicative information messages. The existence of a sign can replace something or a metaphor thought about and contemplated. The science of reading signs originated and developed in the field of linguistics, developments occurred later in the fields of design science and fine arts science. The term semiotics in Greek is semeion, which means sign. Basically, humans like to look for meaning or try to understand all forms of messages that are around, and all are considered to be signs. It is possible to search for sign messages in a way of studying various branches of science, especially visual communication. Refers to how the point of view with these signs can be digested and all are considered to be language phenomena. Referring to CS theory. Pierce, how the sign of an image looks from various types of signs classified in semiotic signs, one of which is an index, icon, symbol. An icon sign that has a resemblance to an object that is representative. It is said to be a sign that has the same characteristics as something that is intended. An example of an image of Maradona being considered the god of football in Argentina is the icon of the Argentine samba team. Gedung Sate is an icon of the Bandung city area. An index is a form of sign that relates to the cause and effect of the representative of the sign or is referred to as a sign that is evidence. For example the presence of smoke and fog, fire. When a fire sign is lit there must be a fire, the bear footprints on the ground are an index of the animal being around the place. 
The shape of the signature stroke is an index representative of the person's existence. A symbol is a sign based on a mutually agreed convention, rule, agreement. Understanding Symbols can be very easy if people understand the meanings that have been agreed upon. For example: For the Indonesian people, Pancasila with the Garuda symbol is a symbol of the state and a symbol of ethnic and cultural diversity.

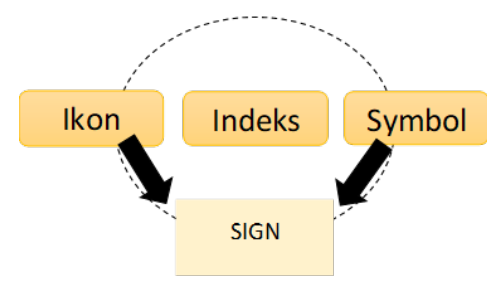

Pigures 3: Semiotic CS. Pierce Personal source

\section{Research Method}

In this research approach, the themes used are interpretive, descriptive, and qualitative with a semiotic approach to communication. Messages and visual signs are focused on using the structural semiotic approach of Charles Sanders Peirce as a method or way of analyzing facts, on the visual form, color of the sign, and the shape of the object as a Signifier and
Signified which produces a "Sign". as a unified whole and comprehensive system produces an analytical point of view according to the scientific background.

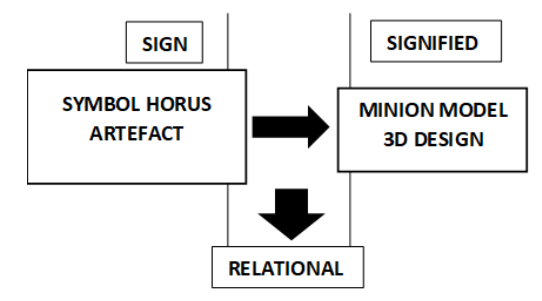

Pigures 4: Analysis of chart semiotic signs

Personal source

In the visual analysis, it is connected with part of the object being analyzed, namely the Stuart Minion character design, then it is related to the perception of the past and modern eye shape symbol. there is a mixture of two elements of eastern culture and western culture. The following is a presentation of the images in the table:

Table 3: Breakdown Visual Element

\begin{tabular}{|l|l|l|l|}
\hline \multicolumn{2}{|c|}{ ICON } & \multicolumn{2}{|c|}{ INDEKS } \\
\hline
\end{tabular}




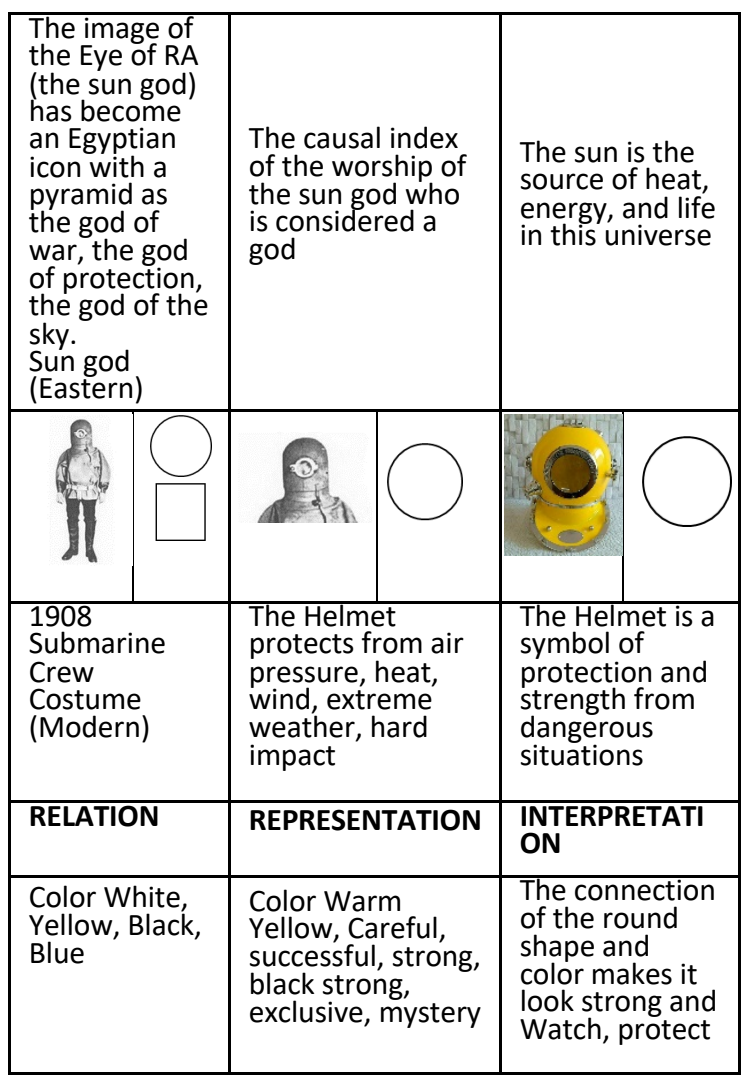

The results of the analysis of various visual categories are how the symbols related to the shape of the one eye in visual culture, especially the shape of the eye of the RA (sun god) from Egypt and other data as a representation of strength, protection, life, energy. How the symbol is related to the analysis of the Minion character in the animation work, namely the character model of Stuart in the work.

Table 4 : Stuart Model breakdown

\begin{tabular}{|l|l|l|}
\hline NO & Minion Model Part & INFORMATION \\
\hline
\end{tabular}

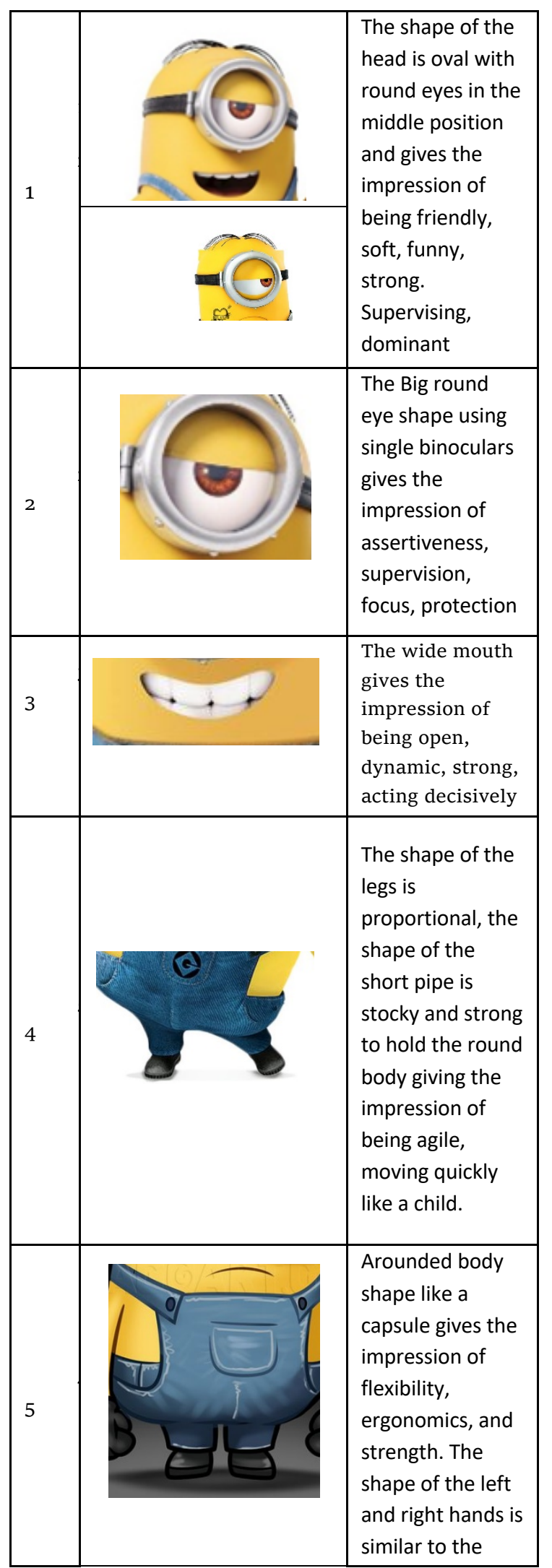




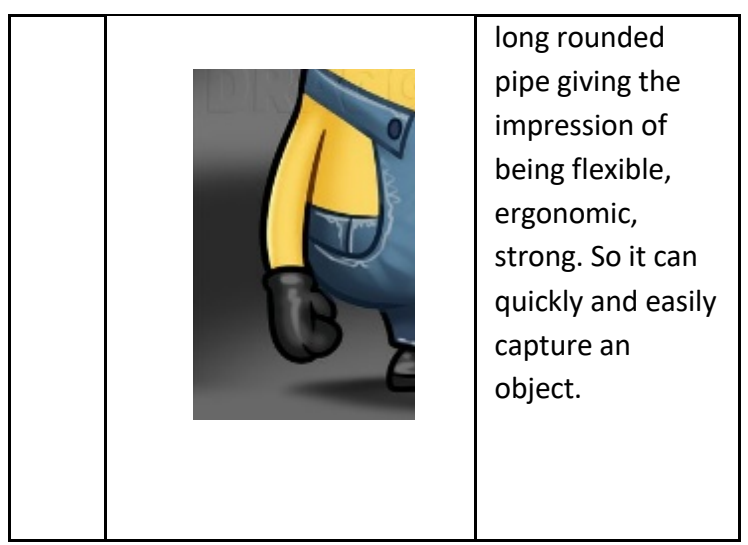

\section{Conclusions}

The conclusion of the two comparisons of visual data from the table above, namely tables 3 and 4, can be analyzed and concluded, for both descriptions of the form based on the interpretation of the two visual objects along with the interpretation of visual objects associated with visual signs which indeed almost resemble the meaning of bunches with the object in question. The analysis is the representation of the shape on the object's sign, the sun symbol or $R A$ (Sun God myth of Egypt) round shape, and the binocular helmet symbol on the Egyptian relief symbol associated with the meaning of the Stuart character in the 3D Minion animated film from the meaning of the sign in terms of icons, indexes, and symbols. That the Stuart minion has the meaning of the same shape. Like there are signs with icons, indexes, and symbols that form the basis of a semiotic study of the Stuart character. With only one round binocular shape, round shape and capsule, yellow color, blue color, the protective clothing that makes this Minion a symbol are very strong and easy to recognize because it communicates a clear and easily recognizable sign language. The minion character named Stuart is a representation of a sign of strength, protection, flexibility, energy is Iconic to also symbolic mixed cultures.

Table 5: strength, protection, flexibility, energy.

\begin{tabular}{|c|c|c|}
\hline \multicolumn{3}{|c|}{ Minion Model Part } \\
\hline SHAPE & COLOR & $\begin{array}{c}\text { SIGN \& } \\
\text { SIGNIFIED }\end{array}$ \\
\hline $\begin{array}{l}\text { The round } \\
\text { element } \\
\text { combined with } \\
\text { the box shape } \\
\text { means } \\
\text { something that } \\
\text { is dynamic, } \\
\text { strong, flexible, } \\
\text { protective, }\end{array}$ & $\begin{array}{l}\text { Yellow color: } \\
\text { signifies } \\
\text { success, } \\
\text { warmth, } \\
\text { energy, } \\
\text { strength, } \\
\text { dynamic. }\end{array}$ & $\begin{array}{l}\text { Sign: Shapes and } \\
\text { colors already } \\
\text { represent the } \\
\text { meaning of the } \\
\text { actual } \\
\text { relationship. }\end{array}$ \\
\hline
\end{tabular}




\begin{tabular}{|c|c|c|}
\hline $\begin{array}{l}\text { friendly, simple, } \\
\text { agile. }\end{array}$ & $\begin{array}{l}\text { Blue color: } \\
\text { signifies } \\
\text { strength, } \\
\text { energy, } \\
\text { dynamic, } \\
\text { coolness, } \\
\text { protecting }\end{array}$ & $\begin{array}{l}\text { Signified: Has the } \\
\text { meaning of the } \\
\text { symbol that } \\
\text { represents it, } \\
\text { namely a round } \\
\text { shape and the } \\
\text { nature of the } \\
\text { meaning of the } \\
\text { form, namely } \\
\text { protection and } \\
\text { strength. }\end{array}$ \\
\hline
\end{tabular}

\section{Acknowledgments}

Thanks to God Almighty. Mother and late father, my little family in Bandung and all my family, co-workers DKV multimedia Tel-U Bandung, all may friends of the DKV Unpas Setiabudi Bandung, DKV Unpas 96, NKOTB bicycle and motorcycle community, 108 community, Telkom University, Etc.

\section{References}

Devianty, R. (2017). Bahasa sebagai cermin kebudayaan. Jurnal tarbiyah, 24(2).

Hoedoro Hoed, Benny. "Kebudayaan sebagai Sistem Tanda'. Diktat Kuliah, Fakultas Sastra UI, Jakarta, 2015.

St Clair, R. N. (2000). Visual Metaphor, Cultural Knowledge, and the New Rhetoric.

Trifonas, P. P. (Ed.). (2015). International handbook of semiotics. Dordrecht: Springer.

Ramdhan, Z., \& Budiman, A. (2016). REPRESENTASI BUDAYA LOKAL (Sub Culture) DAN ESKSISTENSI JATI DIRI DALAM ANIMASI" PADA SUATU KETIKA". Kalatanda: Jurnal Desain Grafis dan Media Kreatif, 1(1), 31-42.
Barnard, M. (1998). Art, design and visual culture: An introduction. Macmillan International Higher Education.

Abdel-Raheem, A. (2020). Moral metaphor and gender in Arab visual culture: Debunking Western myths. Social Semiotics, 30(5), 715-742.

Other sources

https://despicableme.fandom.com/wiki/ Stuart\#Minions

https://www.bbc.com/culture/article/20 201112-the-eye-of-providence-the-

symbol-with-a-secret-meaning

https://despicableme.fandom.com/wiki/ Stuart\#Minions 
First Author Zaini Ramdhan., S.Sn., M.Sn. I graduated from the Bachelor of Arts and Design Faculty of Pasundan University Visual Communication Design Study Program 2003, Masters Degree from the Bandung Indonesian Institute of Arts and Culture (STSI/ISBI) Art Studies Study Program in 2014. Be practical at PT. Animation Telemedia (ATMpro) Jakarta 2003-2006, Greengrafhic Bandung 2006-2008, Becoming a Lecturer at Pasundan University 20082013, Telkom University 2014 until now. The writings and works; representasi budaya lokal (sub culture) dan esksistensi jati diri dalam animasi" pada suatu ketika"z ramdhan, a budiman, Kalatanda: Jurnal Desain Grafis dan Media Kreatif 1 (1), 31-42, Metallus Character Design For Jinn Warriors Comic, Z Ramdhan, M Iskandar, Bandung Creative Movement (BCM) Journal 3 (1). set extention vfx analysis of visual effects from the wiro sableng film the movie, Z Ramdhan, ND Nugraha, Proceeding International Conference on Multimedia, Architecture, and Design. Character Transformation Of Cepot, Z Ramdhan, Y Sudaryat, Bandung Creative Movement (BCM) Journal 2 (1). Kreativitas musik film Sang Pencerah, AA Anwar, A Budiman, Z Ramdhan, ProTVF 4 (2), 223-246. Perancangan Storyboard Pada Animasi Panday Mengenai Informasi Perlindungan Ekosistem Alami Kawasan Cagar Alam Gunung Papandayan. Perancangan Karakter Dari Filosofi Tokoh Prabu Siliwangi Di Kota Purwakarta Dengan Tema Fantasi/supranatural, FB Wicaksono, Z Ramdhan, eProceedings of Art \& Design 7 (2), Perancangan Enviroment Dalam Animasi 3d" sons Of Pandawa", MW Octavian, Z Ramdhan, eProceedings of Art \& Design 6 (3), - Perancangan Visual Background Dalam Game Carakan, LF Pondaag, Z Ramdhan. eProceedings of Art \& Design 6 (3),-Perancangan Karakter Animasi 2d Hanoman Berdasarkan Adaptasi Buku Hanoman Si Buruk Rupa Beriiwa Mulia. AN Gozali, Z Ramdhan. eProceedings of Art \& Design 6 (2)- Perancangan Background Untuk Animasi 2d Lontong Cap Gomeh, ASR Ghifari, A Budiman, Z Ramdhan, eProceedings of Art \& Design 6 (2) 
